\title{
VIII.-HEREDITARY POSTERIOR POLAR CATARACT
}

\section{Ziegler, S. Lewis, and 'Griscom, J. Milton (Philadelphia).- Hereditary posterior polar cataract, with report of a pedi- gree. Trans. Amer. Ophthal. Soc., Vol. XIV, Part i, I9I5, p. 356.}

(7) Aprobos of the explanation of hereditary cataract, Ziegler and Griscom point out there are two schools: the one believing that the cause is toxic, and the other believing that it represents an arrest in development of the lens, due to some inherent abnormality in the germ-cell. There is strong evidence in support of both theories. But it is probable that neither one singly explains every case of congenital cataract, while in some instances both may be active factors.

In the cases reported the opacity was situated on the posterior capsule of the lens, and varied from a small round dot at the posterior pole to a dense circular disc covering the central third of the posterior capsule.

The original member of this family came to the United States from France about 1810, but nothing is known concerning the condition of his eyes. The first member of the family known to have congenital cataracts was a son of this original settler. In the second generation there were nine members, of whom six were affected. The third generation contained thirty-one members, of whom ten were affected. The fourth generation contained twentythree members, of whom seven were affected. A study of the pedigree showed that there were sixty-four members in the four generations, of whom twenty-four (37 per cent.) had congenital cataracts. Of those affected, 43 per cent. were females and 34 per cent. males. The rule of "once free always free" was followed, since in no instance did normal parents produce aftected children.

Charles B. Davenport reported concerning the pedigree that the cataract in this family behaved as dominant. So long as these people with early cataract married, they were bound to perpetuate their trait in half their descendants. Normals, on the other hand, need have no fear of marrying and having children.

S. S.

\section{BOOK NOTICES}

Squint: its causes, pathology and treatment. By CLAUD WorTH, F.R.C.S., Consulting Surgeon to the Royal London Ophthalmic Hospital, Moorfields. Fifth Edition. Baillière, Tindall and Cox. Price 12/6.

We welcome the fifth edition of Worth's book on Squint. In 
comparing it with the first edition issued in 1903, we note that there are now 242 pages instead of 229 . In the appendix appear the results of 100 consecutive advancement operations.

The chapter on operations has been much enlarged. In the first edition the author advised tenotomy to be combined with advancement in severe cases to prevent enophthalmos, now he hardly ever performs tenotomy at all, but where a large effect is necessary in convergent strabismus he advances both external recti, the second operation following the first at an interval of 10 days. After an advancement he keeps both eyes covered for 10 days, and if at the end of this time a further operation is necessary, both will be covered for 20 days. This is a rather serious matter. The author still performs his advancement operation as at first published, but now uses special straight cutting needles for the insertion of the scleral sutures.

The book is well printed and free from errors. The illustrations are the same as those in the first edition.

E. W. B.

\section{Bulletins et Mémoires de la Société française d'Ophtal-} mologie. Thirty-third year, 1920. Paris: MASSON ET CIE., Editeurs, Libraires de l'Académie de Médicine, 120, Boulevard Saint Germain, 6e.

The Bulletins of the French Society of Ophthalmology for 1920 have now been published. The handsome binding in which the volume was issued before the war has been dropped, probably on the ground of expense, and a paper cover is substituted. One of the first things to do, therefore, is to have the volume properly bound. Only six ophthalmic surgeons in Great Britain appear in the list of members, which is a pity, as the French Transactions always contain some valuable articles, and admission to the Society is quite easy. The present number contains 255 pages, of which almost half are occupied by the excellent rapport by Dr. Gonin, of Lausanne, on Idiopathic Detachment of the Retina. The rest of the contents consist of articles of varied interest, including one by Dr. Barraquer, of Barcelona, on the operation which he has called phakoerisis. Extracts from the more interesting papers will be published in this Journal from time to time.

CHARLES Killick.

The Medical Annual, I921. Bristol: John Wright \& Sons, Ltd. London: Simpkin, Marshall, Hamilton, Kent and Co., Ltd. Price 20/- net.

This useful work of reference has again made its annual appearance and maintains the high standard set in its previous thirtyeight years of publication. The ophthalmic section has this year been undertaken by Burdon Cooper. The most important article 
deals with the medical treatment of cataract. The chemical pathology of cataract must necessarily form the basis of any possible medical treatment of this affection. Burdon Cooper has himself done some research work on the subject, and in this all too short summary gives an account of the work of other writers, together with a brief note of Burge's excellent paper on the injurious effect of ultraviolet light on living tissue (Bull. Nela Research Lab. 1919, Vol. I., paper 61). Other articles deal with diseases of the conjunctiva, glaucoma, diseases of the retina and general therapeutics. In addition to several text illustrations, there is an excellent coloured plate of congenital multilocular cysts of the retina reproduced from the Journal of the American Medical Association.

The only criticism we feel inclined to offer on the ophthalmic section is that it is rather more suited for the specialist than for the general practitioner.

E. E. H.

\section{NOTES}

THE following gentlemen were elected to the

North of England Council of the Society at the annual meeting Ophthalmological Society held in April. Session 1921-1922 :-President :

J. Gray Clegg, Manchester; Vice-President : Geo. H. Oliver, Bradford; Hon. Treasurer: Harry Lee, Leeds; Hon.Secretary: Percival J.Hay, Sheffield; Council : A. E. Burroughs, Liverpool, and H. Caiger, Sheffield.

Appointment A. Christil: REID, D.O. (Oxon.) has been appointed surgeon to the Nottingham Eye Infirmary vice Col. H. Herbert (resigned).

Corrigendum In the account given in the last number of the Journal of the meeting of the Ophthalmological Society it was stated that certain stides of malarial parasites in the intraocular vessels were shown by Professor Shattock, whereas the specimens were obtained by Professor Leonard S. Dudgeon at Salonika and exhibited by that gentleman.

\section{Dr. Freeland Fergus}

THE Senate of the University of Glasgow has resolved to confer the honorary degree of Doctor of Laws upon Dr. Freeland Fergus, President of the Royal Faculty of Physicians and Surgeons of Glasgow. 